\title{
Kauran ja ohra-kauraseoksen määrän vaikutus maidontuotannossa
}

\author{
Terttu Heikkilä ja Lea Huida \\ MTT Kotieläintuotannon tutkimus, Eläinravitsemus, 31600 Jokioinen, etunimi.sukunimi@mtt.fi
}

\section{Tiivistelmä}

Kaura on Suomessa ollut perinteisesti pääasiallinen kotoinen vilja lehmien ruokinnassa ja kauraa käytetään edelleenkin enemmän kuin ohraa. Ohran viljely on kuitenkin lisääntynyt ja monet viljelijät käyttävät nykyään ohra-kauraseoksia. Rehutaulukoissa kauran rehuarvo on huonompi kuin ohran, mutta monissa tutkimuksissa kauran on todettu parantavan maitotuotosta ja maidon rasvahappokoostumusta verrattuna ohraan.

Tässä tutkimuksessa selvitettiin kauran ja ohra-kauraseoksen (1:1) määrän $(0,2,0,3,0,4 \mathrm{~kg} / \mathrm{kg}$ 4-\% rasvakorjattua maitoa) vaikutusta maitotuotokseen ja maidon koostumukseen sekä rehun hyväksikäyttöön säilörehuruokinnalla. Väkirehut sisälsivät 96,6 \% viljaa ja 3,4 \% kivennäisseosta. Nurmisäilörehua annettiin vapaasti ja heinää $1 \mathrm{~kg} / \mathrm{pv}$. Koe toteutettiin 2 × 3 faktoriaalisena jatkuvana kokeena 36 ayrshire-lehmällä. Koe kesti kaikkiaan 7 kuukautta alkaen kahden viikon valmistuskaudella, jolloin kaikki lehmät olivat samalla ruokinnalla. Sen jälkeen lehmät siirrettiin koeruokinnoille kahden viikon aikana. Koekausi kesti 24 viikkoa. Valmistuskauden tietoja käytettiin kovarianssianalyysissä. Rehujen sulavuus määritettiin lampailla, joiden perusteella laskettiin rehuarvot.

Viljaväkirehujen syöntimäärät olivat koekaudella edellä mainituilla tasoilla 4,8, 7,5 ja 10,2 $\mathrm{kg} / \mathrm{pv}$ keskimäärin vastaavien osuuksien ollessa 29, 40 ja $51 \%$ rehuannoksen kuiva-aineesta. Molempien väkirehujen määrän nousu 29:stä $51 \%$ :iin vähensi säilörehun syöntiä, mutta lisäsi lineaarisesti kuiva-aineen kokonaissyöntiä, maito-, rasva-, valkuais- ja maitosokerituotosta sekä valkuais/rasvasuhdetta. Maitotuotokset olivat kauratasoilla 19,9, 22,1, 24,3 kg/pv ja ohra-kauraseostasoilla 20,1, $21,7,23,8 \mathrm{~kg} / \mathrm{pv}$ keskimäärin eikä viljojen välillä ollut merkitsevää eroa. Kauran tuotosvaste oli kuitenkin parempi kuin ohra-kauraseoksen ( 0,966 vs. $0,745 \mathrm{~kg}$ maitoa viljan kuiva-ainekilon lisäystä kohti). Energiakorjatun maidon (EKM) tuotosvasteen ero oli pienempi (0,846 vs. 0,781 kg EKM $/ \mathrm{kg}$ viljan kuiva-ainelisäystä), sillä väkirehumäärän lisääntyessä kauraruokinnalla maidon rasvapitoisuus pyrki laskemaan eikä valkuaispitoisuus noussut (rasva 43,9, 42,1, 41,0 g/kg, valkuainen 30,9, 31,5, 31,0 $\mathrm{g} / \mathrm{kg}$ ) verrattuna ohra-kauraseokseen (rasva 42,9, 43,8, 42,6 g/kg, valkuainen 30,3, 32,4, 32,5 g/kg). Öljyhapon osuus maitorasvassa nousi kauramäärän lisääntyessä, kun taas ohra-kauraseoksen määrän noustessa se laski. Maidon juustoutumisominaisuus parani väkirehumäärän lisääntyessä, mutta vähemmän kaura- kuin ohra-kauraseosruokinnalla. Rehun hyväksikäyttöparametrit eivät eronneet merkitsevästi viljojen välillä muutoin kuin, että muuntokelpoisen energian ja ohutsuolesta imeytyvien aminohappojen hyväksikäyttö maidontuotantoon oli parempi kaura- kuin ohra-kauraseosruokinnalla. Maidontuotantokokeen perusteella laskien kauran ja ohra-kauraseoksen energia-arvo oli sama.

Asiasanat: kaura, ohra-kaura, väkirehumäärä, lehmä, maidontuotanto, maidon koostumus

\section{Johdanto}

Ohra ja kaura ovat tärkeimmät rehuviljat Suomessa. Ohrassa on tärkkelystä noin $10 \%$-yksikköä enemmän kuin kaurassa. Valkuaista molemmissa viljoissa on keskimäärin saman verran, mutta laadultaan se on erilaista. Kauran valkuainen sisältää noin 80 \% lysiinirikkaampaa ja liukoisempaa globuliinia, kun taas ohran valkuainen on vaikealiukoisempaa ja lysiiniköyhempää prolamiinia ja gluteliinia. Kaurassa on rasvaa 5-7 \% kuiva-aineessa, josta noin $80 \%$ on tyydyttämättömiä öljy- ja linolihappoa noin puolet kumpaakin. Ohran rasvakin sisältää saman verran tyydyttämättömiä rasvahappoja, joista monityydyttämättömien linoli- ja linoleenihapon osuus on suurempi kuin kaurassa. Ohran rasvan määrä vain on 2-3 kertaa pienempi kuin kauran. Kauran bruttoenergia on sen korkeamman rasvasisällön vuoksi suurempi kuin ohran. Kauran jyvissä on helpeistä muodostunutta kuorta kaksinkertaisesti ohraan verrattuna. Kauran suuremman kuitu- ja pienemmän tärkkelyspitoisuuden vuoksi sen sulavuus on huonompi kuin ohran. Siksi rehutaulukoissa kauran energia-arvo on huonompi kuin ohran. Monissa tutkimuksissa kauran on kuitenkin todettu parantavan maitotuotosta (mm. Moran 1986, Heikkilä ym. 1988, 1990, Martin \& Thomas 1988, Ekern ym. 2003) ja maidon rasvahappokoostumusta verrattuna ohraan (Kankare, V. \& Antila, V. 1984, Martin \& Thomas 1988, Tesfa ym. 1992, Ekern ym. 2003). Ohran viljely on viime vuosina lisääntynyt ja kauran vähentynyt. Vuonna 2005 ohran viljelyala oli 
puolet koko vilja-alasta ja kauran vajaa kolmannes (Tike 2005a). Talousvuonna 2004/05 ohraa käytettiin rehuksi 1077 miljoonaa kiloa ja kauraa 681 miljoonaa kiloa. Ohran kaikesta kotimaisesta kulutuksesta meni rehuksi $66 \%$ ja kauran kulutuksesta $83 \%$. Pääosa rehuviljoista käytetään suoraan maatiloilla: ohrasta 821 ja kaurasta 499 miljoonaa kiloa vuonna 2004/05 (Tike 2005b). Rehuteollisuudessa käytettiin ohraa 257 ja kauraa 182 miljoonaa kiloa. Rehuteollisuus käyttää vehnää jo enemmän kuin kauraa. Maatiloilla rehuksi käytetystä kaurasta syötettiin $76 \%$ nautakarjalle (379 milj. kg) ja ohrasta $44 \%$ (359 milj. kg) (Tike 2005c, Kuva s. 6). Kun lihakarja syö ohrasta osan, niin voidaan edelleen sanoa, että keskimäärin kauraa syötetään lehmille enemmän kuin ohraa. Kaura on Suomessa ollut perinteisesti pääasiallinen kotoinen vilja lehmien ruokinnassa. Pelkän kauran käyttö rehuviljana lehmille on yleisempää tiloilla kuin pelkän ohran käyttö (ProAgrian rehunkulutustilastot, Juho Kyntäjä, suullinen tiedonanto). Monet maidontuottajat käyttävät rehuviljana kuitenkin nykyään ohra-kauraseoksia.

Tässä tutkimuksessa selvitettiin kauran ja ohra-kauraseoksen (1:1) määrän vaikutusta maitotuotokseen ja maidon koostumukseen sekä rehun hyväksikäyttöön säilörehuruokinnalla.

\section{Aineisto ja menetelmät}

Maidontuotantokoe toteutettiin 36 Ay-lehmällä MTT:n Jokioisten Kartanoiden Lintupajun lehmäkoenavetassa 2 x 3 faktoriaalisena jatkuvana kokeena. Tutkittavina tekijöinä oli kaksi väkirehua: kaura- ja ohra-kaura(1:1)-kivennäisseos ainoina väkirehuina ja kolme väkirehumäärää: 0,2, 0,3 ja 0,4 kg väkirehua 4-\% maitokiloa kohti. Väkirehut sisälsivät 96,6 \% viljaa ja 3,4 \% kivennäisseosta. Viljojen hehtolitrapainot määritettiin viikoittain. Väkirehua annettiin 4-\%:n maitotuotoksen mukaan ja sen määrää tarkistettiin neljän viikon välein. Säilörehua annettiin vapaasti (20 tuntia/vrk) ja heinää kilo päivässä. Säilörehu oli korjattu kelasilppurilla tuoreena, pääasiassa eri heinäkasvinurmien (nurminata-timoteipuna-apila, koiranheinä-timotei ym., timotei-nurminata-Englannin-raiheinä) 1. tai 2. sadosta ja säilötty laakasiiloihin hapolla- tai biologisilla säilöntäaineilla (AIV 2:1la tai maitohappobakteeri+entsyymiseoksilla, joissa lisänä oli natriumbentsoaatti tai natriumformiaatti) tai ilman säilöntäainetta (painorehu). Samaa säilörehua syötettiin aina kaikille lehmille kerrallaan. Happo- ja bakteeri+entsyymirehuja syötettiin molempia 10 viikkoa ja painorehua 4 viikkoa. Toista satoa syötettiin vain 6 viikkoa alussa.

Koe kesti kaikkiaan 7 kuukautta, josta kaksi ensimmäistä viikkoa oli ns. valmistuskautta, jolloin kaikki eläimet olivat samalla ruokinnalla, ja jonka tietojen perusteella lehmät jaettiin kuuteen mahdollisimman samanlaiseen kuuden lehmän koeryhmään maitotuotoksen, maidon rasva- ja valkuaispitoisuuden, säilörehun syönnin, elopainon, poikimisesta kuluneen ajan ja laktaatiokauden mukaan. Sitten lehmät siirrettiin koeruokinnoille kahden viikon aikana. Koekausi kesti 24 viikkoa, jota seurasi kahden viikon jälkikausi samalla ruokinnalla. Lehmät olivat poikineet keskimäärin 3,4 kertaa ja poikimisesta oli kulunut koeruokinnan alkaessa 68 päivää. Maitotuotos oli 29,6 kg keskimäärin ja elopaino $591 \mathrm{~kg}$. Rehut, jätteet ja maidot punnittiin eläimittäin joka päivä. Lehmät punnittiin valmistus-, koe- ja jälkikauden alussa ja lopussa sekä koekaudella neljän viikon välein kahtena peräkkäisenä päivänä. Rehunäytteet otettiin päivittäin rehun punnituksen yhteydessä ja kahden viikon keruunäytteistä tehtiin rehuanalyysi, neutraali- ja happodetergenttikuidut (NDF ja ADF). Viljoista analysoitiin lisäksi tärkkelys ja rasvahapot sekä säilörehusta käymislaatu. Maitonäytteet otettiin joka viikko neljänä peräkkäisenä lypsykertana rasva-, valkuais- ja maitosokerimäärityksiin jokaiselta lehmältä ja vastaavasti joka toinen viikko otettiin kahden päivän maidosta ryhmänäytteet, urea- ja rasvahappomäärityksiin sekä yhden päivän maidosta juoksettuvuusmäärityksiin. Rehujen sulavuus määritettiin neljällä lampaalla. Väkirehun sulavuusmäärityksessä oli viljaa ja säilörehua puolet kumpaakin kuiva-aineena laskien. Syönti- ja tuotostiedot analysoitiin tilastollisesti kovarianssianalyysillä (SAS:n GLM), jossa valmistuskauden vastaava muuttuja oli kovariaattina. Malleissa oli väkirehun, sen määrän vaikutukset ja niiden yhdysvaikutukset. Kontrastein tutkittiin väkirehumäärän lineaarinen ja toisen asteen vaikutus.

\section{Tulokset ja tulosten tarkastelu}

Viljojen koostumus oli keskimäärin hyvän viljan luokkaa (Taulukko 1), mutta vaihtelua esiintyi. Viljojen hehtolitrapainot olivat keskimäärin kauralla 57,1 (vaihtelu 48,2-59,7) ja ohralla 63,4 (vaihtelu $51,1-72,6) \mathrm{kg} / \mathrm{hl}$. Kauran raakavalkuaispitoisuus oli kuuden ensimmäisen koeviikon aikana keskimääräistä korkeampi (154 g/kg ka), samoin raakakuitu (107 g/kg ka) ja raakarasva pienempi (48 g/kg ka). Kauran rasvapitoisuus vaihteli 46-68 ja ohra-kauran 34-47 g/kg ka. Kauraseoksen rasva sisälsi keskimäärin palmitiini-, steariini-, öljy-, linoli- ja linoleenihappoa 16,2, 1,3, 39,8, 39,8 ja 2,9 \% kokonais- 
rasvahapoista ja ohra-kauraseoksen rasva sisälsi vastaavasti 16,9, 1,2, 32,6, 44,8 ja 4,6 \%. Säilörehun D-arvo vaihteli 64,5-70,5\% ja raakavalkuaispitoisuus $159-188 \mathrm{~g} / \mathrm{kg} \mathrm{ka}$.

Taulukko 1. Kauran, ohra-kauraseoksen (1:1), säilörehun ja heinän koostumus ja rehuarvo keskimäärin

\begin{tabular}{|c|c|c|c|c|c|c|c|c|c|c|c|}
\hline Rehut & $\begin{array}{l}\text { Kuiva- } \\
\text { aine } \\
\mathrm{g} / \mathrm{kg}\end{array}$ & $\begin{array}{l}\text { Raaka- } \\
\text { valk. }\end{array}$ & $\begin{array}{l}\text { Raaka- } \\
\text { rasva }\end{array}$ & $\begin{array}{l}\text { Raaka- } \\
\text { kuitu } \\
\text {-g/kg ka- }\end{array}$ & $\mathrm{NDF}$ & $\mathrm{ADF}$ & $\begin{array}{l}\text { Tärk- } \\
\text { kelys }\end{array}$ & $\begin{array}{c}\mathrm{ry} / \\
\mathrm{kg} \mathrm{ka}\end{array}$ & $\begin{array}{l}\text { OIV } \\
---g / 1\end{array}$ & $\begin{array}{l}\text { PVT } \\
\text { ka--- }\end{array}$ & $\begin{array}{c}\text { D- } \\
\text { arvo } \\
\%\end{array}$ \\
\hline \multicolumn{12}{|l|}{ Väkirehut ${ }^{1}$} \\
\hline Kaura & 886 & 131 & 58 & 97 & 261 & 119 & 456 & 1,08 & 95 & -23 & 74 \\
\hline $\begin{array}{l}\text { Ohra-kaura } \\
\text { Karkearehut }\end{array}$ & 886 & 135 & 40 & 71 & 251 & 88 & 507 & 1,15 & 103 & -33 & 82 \\
\hline Säilörehu & 222 & 170 & 57 & 278 & 510 & 296 & & 0.9 & 84 & 27 & 68 \\
\hline Heinä & 872 & 95 & 18 & 355 & 684 & 393 & & 0,73 & 74 & -31 & 57 \\
\hline
\end{tabular}

${ }^{1}$ Väkirehut ovat vilja-kivennäisseoksia. Rehuarvot on laskettu lampailla määritetyn sulavuuden mukaan.

Hapolla ja biologisilla säilöntäaineilla tehdyt säilörehut olivat hyvälaatuisia (Taulukko 2). Painorehun pH oli korkeampi ja käymislaatu vähän heikompi, mikä heijastui sen syöntiin. Painorehua lehmät söivät keskimäärin 20, 18 ja $13 \%$ vähemmän kuin säilöntäaineella tehtyjä rehuja väkirehutasoilla 29, 40, $51 \%$ kuiva-aineesta eli säilörehun laadun vaikutus syöntiin väheni väkirehumäärän lisääntyessä.

Taulukko 2. Säilörehujen käymislaatu säilöntäaineittain keskimäärin

\begin{tabular}{cccccccccc}
\hline $\begin{array}{c}\text { Säilörehu/ } \\
\text { Säilöntäaine }\end{array}$ & $\begin{array}{c}\text { Kuiva- } \\
\text { aine } \\
\text { g/kg }\end{array}$ & pH & Sokeri & $\begin{array}{c}\text { Maito- } \\
\text { happo }\end{array}$ & $\begin{array}{c}\text { Etikka- } \\
\text { happo }\end{array}$ & $\begin{array}{c}\text { Propioni- } \\
\text { happo }\end{array}$ & $\begin{array}{c}\text { Voi- } \\
\text { happo }\end{array}$ & $\begin{array}{c}\text { Etanoli }^{2} \\
\mathrm{NH}_{4^{-}} \\
\mathrm{N} \\
\mathrm{g} / \mathrm{kg} \mathrm{N}\end{array}$ \\
\hline AIV 2 & 215 & 4,11 & 48 & 39 & 16 & 0,2 & 0,7 & 4,0 & 42 \\
Bakt.+ ents. & 234 & 4,04 & 52 & 102 & 14 & 0,4 & 0,6 & 6,8 & 34 \\
Painorehu & 206 & 4,25 & 16 & 86 & 20 & 1,5 & 1,2 & 7,3 & 73 \\
\hline
\end{tabular}

Viljaväkirehujen syöntimäärät eri tasoilla olivat keskimäärin 4,8, 7,5 ja 10,2 kg päivässä ja vastaavat väkirehun osuudet olivat 29,40 ja $51 \%$ rehuannoksen kuiva-aineen syönnistä. Korkeimmalla väkirehutasolla lehmät söivät kuuden ensimmäisen koeviikon aikana keskimäärin kauraväkirehua $11,7 \mathrm{~kg}$ ja ohra-kauraseosta $12,2 \mathrm{~kg} / \mathrm{pv}$ ja suurimmat keskimääräiset väkirehun syöntimäärät olivat kauraryhmässä $13,5 \mathrm{~kg} / \mathrm{pv}$ ja ohra-kauraryhmässä $13,7 \mathrm{~kg}$. Korkeatuottoisimmat lehmät söivät enimmillään yli 14 $\mathrm{kg} / \mathrm{pv}$ molempia väkirehuja päivässä. Eläinten välillä oli yksilöllisiä eroja ja päivittäistä vaihtelua väkirehun syönnissä varsinkin korkeimmilla annostustasoilla kokeen alussa. Jotkut jättivät väkirehuaan ja söivät säilörehua enemmän ja päinvastoin.

Molempien väkirehujen määrän nousu $29 \rightarrow 51$ prosenttiin vähensi säilörehun syöntiä korvaussuhteen ollessa kauralla 0,438 ja ohra-kauralla 0,264 , mutta lisäsi lineaarisesti kuiva-aineen kokonaissyöntiä, energian ja valkuaisen saantia, maito-, EKM-, rasva-, valkuais- ja maitosokerituotosta sekä valkuais/rasva-suhdetta. Viljojen välillä ei ollut merkitsevää eroa (Taulukko 3), vaikka suuntaa antavasti ohra-kauraruokinnalla korkeammilla väkirehutasoilla lehmät saivat rehuyksiköitä ja OIV:tä enemmän kuin kauraruokinnalla. Kauran tuotosvaste oli kuitenkin parempi kuin ohra-kauraseoksen ( 0,966 vs. $0,745 \mathrm{~kg}$ maitoa viljan kuiva-ainekilon lisäystä kohti). Energiakorjatun maidon tuotosvasteen ero oli pienempi (0,846 vs. 0,781 kg EKM per kg viljan kuiva-ainelisäystä), sillä väkirehumäärän lisääntyessä maidon rasvapitoisuus pyrki laskemaan kauraruokinnalla $(\mathrm{P}=0,122)$ eikä kauramäärän lisäys nostanut maidon valkuaispitoisuutta. Maidon valkuaispitoisuudessa oli yhdysvaikutus viljan ja väkirehutason lineaarisen vaikutuksen välillä $(\mathrm{P}<0,027)$. Ohra-kauraseoksella maidon valkuaispitoisuus nousi $(\mathrm{P}=0.002)$, mutta vain vähän kahden ylimmän väkirehutason välillä (toisen asteen vaikutus, $P=0.097$ ). Valkuaistuotoksessa viljojen välillä ei kuitenkaan ollut eroa. Ryhmänäytteistä määritetyt maidon korkeammat ureapitoisuudet kauraruokinnalla johtuivat ainakin osaksi kauran korkeasta raakavalkuaispitoisuudesta kokeen alkuvaiheessa.

Väkirehumäärän lisääntyessä energiaa kului enemmän tuotettua energiakorjattua maitokiloa kohti ja muuntokelpoisen energian sekä ohutsuolesta imeytyvien aminohappojen (OIV) hyväksikäyttö maidontuotantoon huononi. Kuiva-ainetta kohti laskettaessa EKM-tuotoksessa ei ollut eroa väkirehu- 
tasojen eikä viljojen välillä. Kauraruokinnalla energian ja OIV:n hyväksikäyttö maidontuotantoon olivat paremmat kuin ohra-kauraruokinnalla $(\mathrm{P}<0,05)$. Rehuvalkuaisen hyväksikäyttö maitovalkuaisen tuotantoon parani väkirehumäärän lisääntyessä enemmän kaura- kuin ohra-kauraruokinnalla.

Elopainossa ja elopainon muutoksessa oli yhdysvaikutusta viljan ja väkirehutason lineaarisen vaikutuksen välillä $(\mathrm{P}<0,05)$. Kauraruokinnalla lehmät laihtuivat hieman korkeimmallakin väkirehutasolla, kun taas ohra-kauraruokinnalla eläimet menettivät painoaan vain alimmalla väkirehutasolla ja lihoivat kahdella korkeimmalla väkirehutasolla suunnaten energiaa enemmän kudoksiin (Taulukko 3).

Taulukko 3. Kauran tai kaura-ohraseoksen (1:1) määrän vaikutus säilörehun syöntiin, maidon tuotantoon ja maidon koostumukseen sekä rehun hyväksikäyttöön

\begin{tabular}{|c|c|c|c|c|c|c|c|c|c|c|c|}
\hline & \multirow{2}{*}{\multicolumn{3}{|c|}{$\begin{array}{c}\text { Kaura } \\
(\mathrm{K})\end{array}$}} & \multirow{2}{*}{\multicolumn{3}{|c|}{$\begin{array}{c}\text { Ohra-kaura 1:1 } \\
(\mathrm{OK})\end{array}$}} & \multirow{4}{*}{ SEM } & \multicolumn{4}{|c|}{ Tilastollinen merkitsevyys } \\
\hline & & & & & & & & \multirow{3}{*}{$\begin{array}{l}\mathrm{K} / \\
\mathrm{OK}\end{array}$} & \multirow{3}{*}{$\begin{array}{c}\text { Väkir } \\
\text { määrä } \\
\text { Lin. }\end{array}$} & \multirow{3}{*}{\multicolumn{2}{|c|}{$\begin{array}{c}\mathrm{K} \quad \mathrm{OK} \\
\text { määrä } \\
\text { Lin }\end{array}$}} \\
\hline & 0,2 & 0,3 & 0,4 & 0,2 & 0,3 & 0,4 & & & & & \\
\hline & \multicolumn{3}{|c|}{$\mathrm{kg} / 4-\%$ maito-kg } & \multicolumn{3}{|c|}{$\mathrm{kg} / 4-\%$ maito- $\mathrm{kg}$} & & & & & \\
\hline \multicolumn{12}{|l|}{ Syönti } \\
\hline 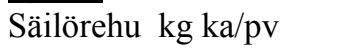 & 10,0 & 9,2 & 8,0 & 9,5 & 9,7 & 8,3 & 0,37 & & $* * *$ & $* * *$ & $*$ \\
\hline Väkirehu " & 4,4 & 6,7 & 9,0 & 4,2 & 6,7 & 9,1 & 0,34 & & $* * *$ & $* * *$ & $* * *$ \\
\hline Yhteensä & 14,8 & 16,4 & 17,2 & 14,3 & 17,0 & 17,7 & 0,56 & & $* * *$ & $* * *$ & $* * *$ \\
\hline Väkirehun osuus, \% & 29 & 41 & 51 & 30 & 40 & 51 & 1,4 & & $* * *$ & $* * *$ & $* * *$ \\
\hline Ry-saanti/pv & 14,4 & 16,2 & 17,3 & 14,2 & 17,2 & 18,5 & 0,58 & 0,175 & $* * *$ & $* *$ & $* * *$ \\
\hline OIV-saanti g/pv & 1286 & 1446 & 1543 & 1274 & 1546 & 1655 & 51,9 & 0,126 & $* * *$ & $* *$ & $* * *$ \\
\hline PVT g/pv & 172 & 99 & 15 & 109 & 30 & -83 & 12,5 & $* * *$ & $* * *$ & $* * *$ & $* * *$ \\
\hline Dieetin r-valk.g/kg ka & 158 & 154 & 150 & 158 & 155 & 151 & 0,06 & & $* * *$ & $* * *$ & $* * *$ \\
\hline \multicolumn{12}{|l|}{$\underline{\text { Tuotos }}$} \\
\hline $\mathrm{kg} / \mathrm{pv}$ & 19,9 & 22,1 & 24,3 & 20,1 & 21,7 & 23,8 & 1,03 & & $* * *$ & $* *$ & $*$ \\
\hline EKM & 20,5 & 22,3 & 24,4 & 20,4 & 22,7 & 24,2 & 1,15 & & $* *$ & $*$ & $*$ \\
\hline Rasva & 868 & 925 & 1000 & 860 & 949 & 995 & 51,6 & & $*$ & o & o \\
\hline Valkuainen “ & 612 & 693 & 750 & 604 & 700 & 763 & 30,7 & & $* * *$ & $* *$ & $* * *$ \\
\hline Maitosokeri “ & 951 & 1054 & 1174 & 976 & 1055 & 1153 & 57,8 & & $* *$ & $*$ & $*$ \\
\hline \multicolumn{12}{|l|}{ Maidon koostumus } \\
\hline $\begin{array}{ll}\text { Rasva } & \mathrm{g} / \mathrm{kg}\end{array}$ & 43,9 & 42,1 & 41,0 & 42,9 & 43,8 & 42,6 & 1,30 & & & 0,122 & \\
\hline Valkuainen "“ & 30,9 & 31,5 & 31,0 & 30,3 & 32,4 & 32,5 & 0,47 & 0,135 & $*$ & & $* *$ \\
\hline Maitosokeri “، & 47,9 & 47,7 & 48,4 & 48,5 & 48,4 & 48,4 & 0,56 & & & & \\
\hline Valk./rasvasuhde & 0,71 & 0,75 & 0,77 & 0,71 & 0,75 & 0,77 & 0,021 & & $* * *$ & $*$ & o \\
\hline Urea, mg/100 ml & 29,4 & 33,9 & 27,2 & 29,3 & 28,2 & 24,3 & & & & & \\
\hline \multicolumn{12}{|l|}{ Rehun hyväksikäyttö } \\
\hline ry/EKM & 0,46 & 0,48 & 0,51 & 0,48 & 0,52 & 0,52 & 0,014 & $*$ & $* *$ & $*$ & o \\
\hline $\mathrm{EKM} / \mathrm{kg} \mathrm{ka}$ & 1,37 & 1,35 & 1,41 & 1,41 & 1,33 & 1,35 & 0,054 & & & & \\
\hline Energian hyv.käyttö, kl & 0,64 & 0,58 & 0,55 & 0,58 & 0,52 & 0,53 & 0,025 & $*$ & $* *$ & $*$ & 0,141 \\
\hline Maidon N/Rehun N, \% & 26,1 & 27,5 & 29,2 & 26,7 & 26,9 & 28,2 & 0,94 & & $*$ & * & \\
\hline Valk.tuotos/OIV-saanti & 0,48 & 0,48 & 0,49 & 0,47 & 0,46 & 0,46 & 0,014 & 0,121 & & & \\
\hline OIV:n hyväksikäyttö & 0,70 & 0,68 & 0,66 & 0,66 & 0,63 & 0,63 & 0,022 & $*$ & 0,105 & & \\
\hline Elopaino kg & 568 & 587 & 577 & 553 & 580 & 597 & 8,0 & & $* *$ & & $* * *$ \\
\hline Elopainon muutos $\mathrm{g} / \mathrm{pv}$ & -149 & -30 & -17 & -328 & 55 & 172 & 81,3 & & $* * *$ & & $* * *$ \\
\hline
\end{tabular}

$\mathrm{EKM}=$ energiakorjattu maito, $\mathrm{OIV}=$ ohutsuolesta imeytyvät aminohapot

Energian hyväksikäytössä $(\mathrm{kl})$ on huomioitu elopainon muutos

Kauralla tuotettu maitorasva sisälsi enemmän öljy- ja steariinihappoa ja vähemmän palmitiinihappoa kuin ohra-kauraseoksella tuotettu. Öljyhapon osuus maitorasvan rasvahapoista nousi kauramäärän lisääntyessä, mutta ohra-kauraseoksen noustessa se laski. Maidon juustoutumisominaisuudet (juoksettuman kiinteys ja kiinteytymisaika) paranivat väkirehumäärän lisääntyessä, mutta vähemmän kaurakuin ohra-kauraseosruokinnalla (Taulukko 4). Kauralla tuotetaan ravitsemuksellisesti hieman terveellisempää maitorasvaa kuin ohra-kauraseoksella. Juustonvalmistuksen kannalta kaura sen sijaan on hieman epäedullisempi, sillä maidon valkuaispitoisuus on yleensä alempi kaura- kuin ohraruokinnalla. Se johtuu todennäköisesti kauran suuremmasta rasvan määrästä. Rasvan saannin ero kaura- ja ohrakauraväkirehusta oli korkeimmassa väkirehuryhmässä keskimäärin $155 \mathrm{~g}$ ja enimmilläänkin vain reilut 
$200 \mathrm{~g} / \mathrm{pv}$. Energiavajaus voi olla myös alhaisen valkuaispitoisuuden syynä. Alemmasta maidon valkuaispitoisuudesta huolimatta kauraruokinnalla tiinehtyvyys oli parempi, ensimmäisestä + toisesta siemennyksestä tiinehtyi $12+5$ lehmää, kun ohra-kaura-ruokinnalla vastaavat luvut olivat $9+2$ lehmää.

Taulukko 4. Kauran ja ohra-kauraseoksen (1:1) määrän vaikutus maitorasvan koostumukseen (\% kokonaisrasvahapoista) ja maidon juoksettumisominaisuuksiin keskimäärin ryhmänäytteistä määritettynä

\begin{tabular}{|c|c|c|c|c|}
\hline \multicolumn{2}{|c|}{ Kaura } & \multicolumn{3}{|c|}{ Ohra-kaura 1:1 } \\
\hline 0,2 & 0,4 & 0,2 & 0,3 & 0,4 \\
\hline \multicolumn{2}{|c|}{$\mathrm{kg} / 4-\%$ maito-kg } & \multicolumn{3}{|c|}{$\mathrm{kg} / 4-\%$ maito-kg } \\
\hline
\end{tabular}

\begin{tabular}{|c|c|c|c|c|c|c|c|}
\hline \multicolumn{8}{|c|}{ Maitorasvan koostumus } \\
\hline Palmitiinihappo, & $\mathrm{C} 16: 0$ & 30,5 & 30,5 & 29,3 & 32,3 & 33,6 & 33,1 \\
\hline Steariinihappo & C18:0 & 12,7 & 12,7 & 13,3 & 11,5 & 10,7 & 11,0 \\
\hline Öljyhappo & C18:1 & 23,4 & 24,1 & 25,2 & 23,6 & 21,2 & 20,6 \\
\hline Linolihappo & $\mathrm{C} 18: 2$ & 1,1 & 1,2 & 1,3 & 1,3 & 1,3 & 1,4 \\
\hline Linoleenihappo & C18:3 & 0,9 & 0,7 & 0,8 & 1,2 & 1,1 & 0,8 \\
\hline \multicolumn{8}{|c|}{ Maidon juoksettuvuus } \\
\hline \multicolumn{2}{|c|}{$\overline{\text { Juoksettuman kiinteys }}_{10} \mathrm{~mm}$} & 20,4 & 24,4 & 26,5 & 20,7 & 27,3 & 29,0 \\
\hline “ kiinteytym & nisaika $\mathrm{K}_{20} \mathrm{~min}$ & 19,2 & 16,5 & 14,7 & 17,6 & 15,2 & 14,2 \\
\hline
\end{tabular}

Maidontuotantokokeen perusteella laskettuna kauran ja ohra-kauraseoksen energia-arvoksi saatiin keskimäärin sama 1,04 ry/kg ka, mikä on selvästi huonompi kuin lampailla määritettyjen sulavuuskertoimien perusteella lasketut rehuarvot taulukossa 1. Rehutaulukossa (MTT 2004) kauran energia-arvo $(1,03-1,05 \mathrm{ry} / \mathrm{kg} \mathrm{ka})$ vastaa hyvin tämän tuotantokokeen antamaa energia-arvoa, mutta ohra-kauraseokselle tuotantokokeessa saatu energia-arvo on $4 \%$ huonompi kuin rehutaulukossa $(1,08 \mathrm{ry} / \mathrm{kg} \mathrm{ka})$ osoittaen ohran yliarvostusta maidontuotannossa. Tämä on yhdenmukainen aiemmin kauran ja ohran vertailussa todetun havainnon kanssa, että kauran rehuarvo on ohran rehuarvoa parempi maidontuotannossa (Lampila \& Heikkilä 1986, Heikkilä ym.1988, 1990). Energian ja valkuaisen parempi hyväksikäyttö kaura- kuin ohra-kauraruokinnalla todettiin myös aiemmassa kokeessa säilörehun ja väkiheinän ollessa perusrehuna (Heikkilä ym. 1995).

\section{Johtopäätös}

Kauran ja ohra-kauraseoksen (1:1) energia-arvo on sama maidontuotannossa tuotantokokeen perusteella laskien.

\section{Kirjallisuus}

Ekern, A., Havrevoll, Ø., Haug, A., Berg, J. Lindstad, P. \& Skeie, S. 2003. Oat and barley based concentrate supplements for dairy cows. Acta Agriculturae Scandinavica, Section A, Animal Science 53: 65-73.

Heikkilä, T., Väätäinen, H. \& Lampila, M. 1988. Barley or oats for dairy cows? Proceedings VI World Conference on Animal Production Helsinki 1988, p. 336.

Heikkilä, T., Väätäinen, H. \& Lampila, M. 1990. Kaura ja ohra lehmien rehuna. Koetoiminta ja Käytäntö 47:46 Heikkilä, T., Väätäinen, H., Toivonen, V.. 1995. Ohra-kauraseoksen ja kauran vaikutus maidontuotannossa heinä ja säilörehuruokinnalla. In: Agro-Food '95 Tampere 13.-15.11.1995 Agro-Food ry. p. B32.

Kankare, V. \& Antila, V. 1984. The effect of feed grains on the fatty acid composition of milk fat. Journal of Agricultural Science in Finland. 56: 33-38.

Lampila, M. \& Heikkilä, T. 1986. Ohraa vai kauraa lypsylehmille? Karjatalous 4: 35-36.

Martin, P.A. \& Thomas, P.C. 1988. Dietary manipulation of the yield and composition of milk: Effects of dietary inclusion of barley and oats in untreated or formaldehyde treated forms on milk fatty acid composition. Journal of the Science of Food and Agriculture 43: 145-154.

Moran, J.B. 1986. Cereal grains in complete diets for dairy cows: A comparison of rolled barley, wheat and oats and of three methods of processing oats. Animal Production 43: 27-36.

Tike 2005a, b, c. Tiken tiedotteet 29.11, 16.9. ja 25.8.2005. Maa- ja metsätalousministeriön tietopalvelukeskus.

Saatavilla internetissä osoitteessa: http://www.mmmtike.fi/TIKE/fi/index/tiedotteet/tiedotteet2005.html

MTT 2004. Rehutaulukot ja ruokintasuositukset. 82 s. Saatavilla internetissä: http://www.agronet.fi/rehutaulukot Tesfa, A.T., Tuori, M., Syrjälä-Qvist, L. \& Kaustell, K.1992. Effects of partial replacement of barley with rapeseed oil or birch wood in comparison to barley and oats on the performance and blood metabolites of lactating cows. Agricultural Science in Finland 1: 255-265. 


\section{KAURAN JA OHRAN VILJELY- JA REHUKSIKÄYTTÖTIETOJA SUOMESSA}

Lähteet: Suomen virallinen tilasto, III: Maatalous, Maatilatilastollinen vuosikirja, Maataloustilastollinen kuukausikatsaus, Maatilahallitus/ Maa- ja metsätalousministeriön tietopalvelukeskus (TIKE), Tietovakka ja Tiken tiedotteet -2005, Helsinki

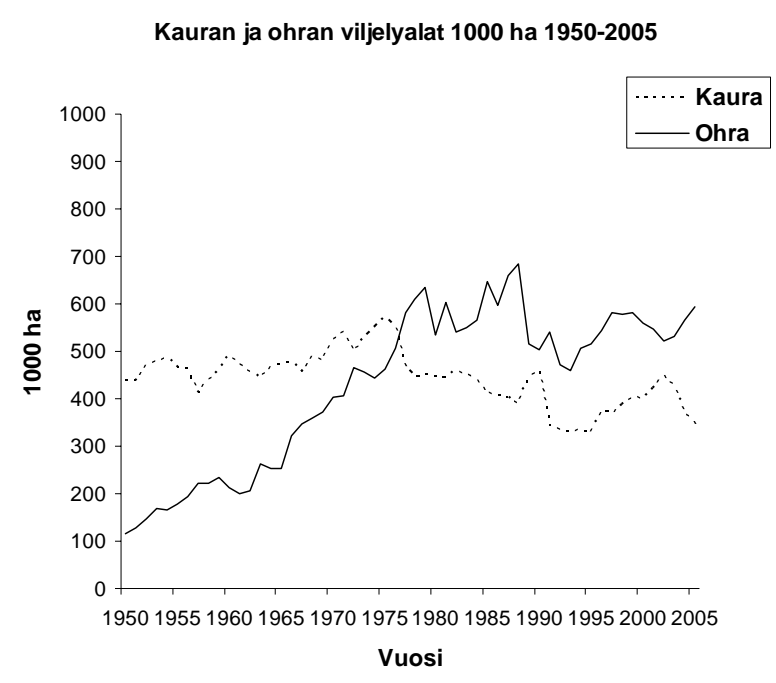

Kauran ja ohran käyttö rehuksi maatiloilla 1970-2005

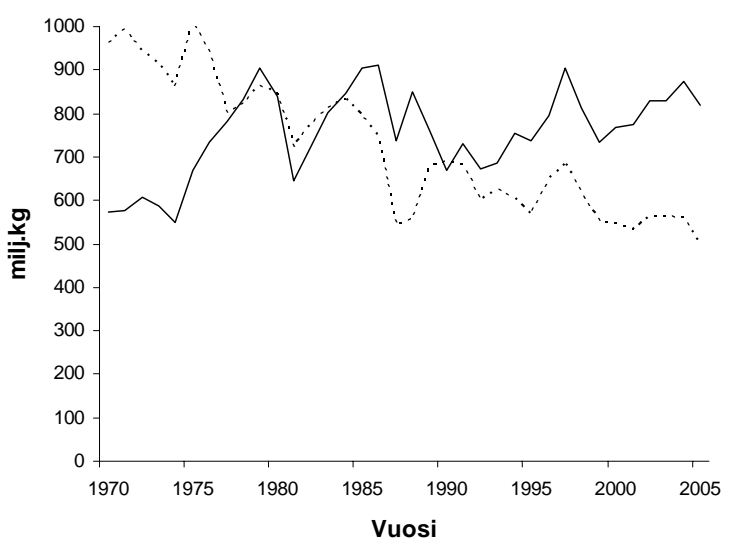

Kauran ja ohran kokonaissato milj.kg 1950-2005

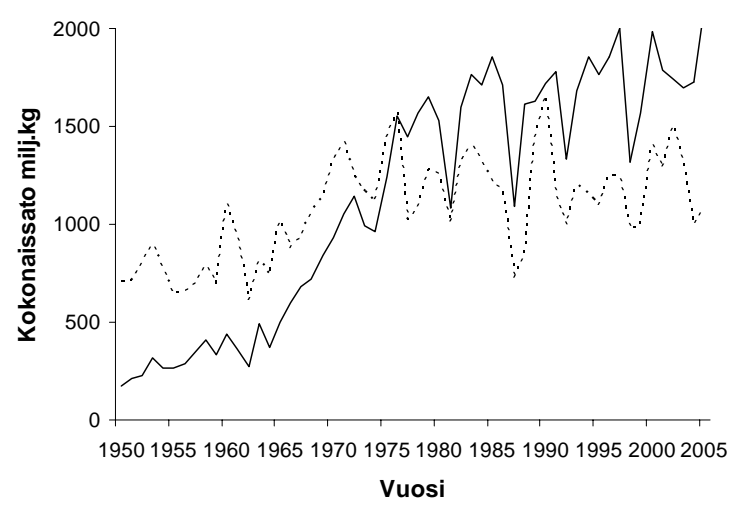

Kauran ja ohran käyttö rehuteollisuudessa 1980-2005

$$
\text { milj.kg }
$$

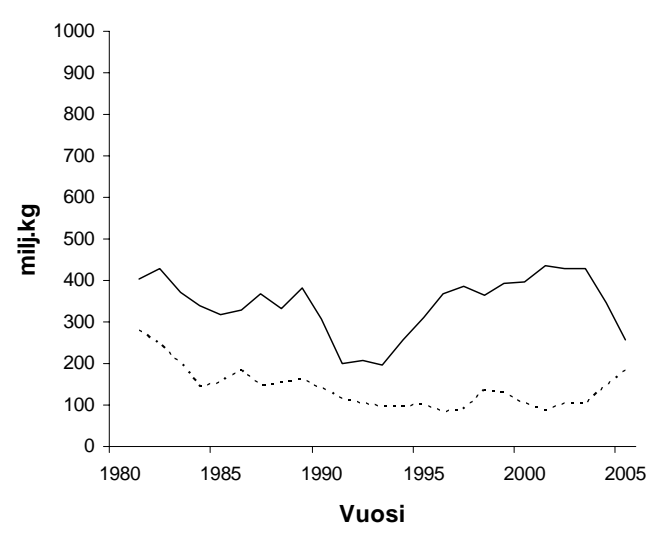

Kauran ja ohran hehtaarisato 1950-2005

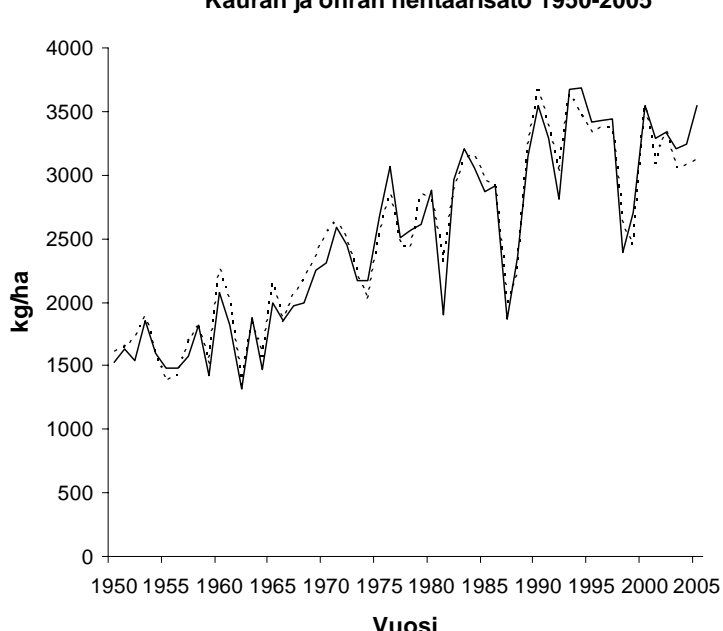

Kauran ja ohran käyttö nautakarjalle maatiloilla 1970-2005

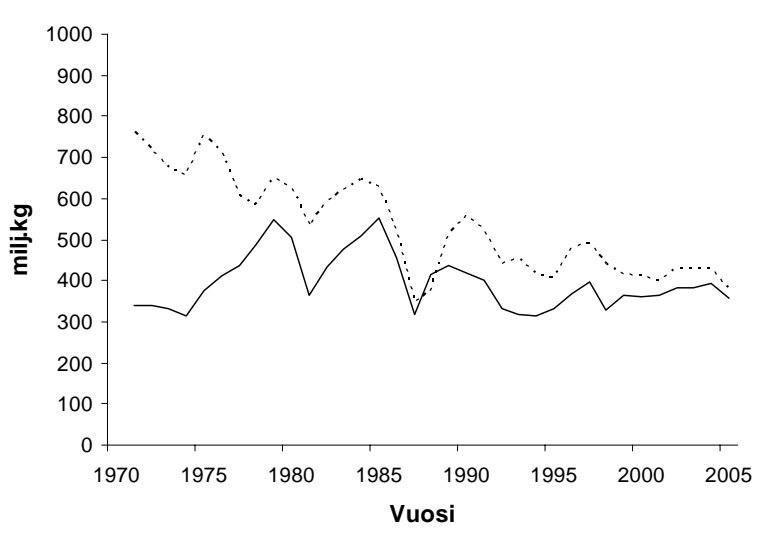

